\title{
FDA under pressure to relax drug rules
}

\section{Industry says antibiotic pipeline is being blocked by overly stringent clinical-trial requirements for new treatments.}

\section{BY HEIDI LEDFORD}

$\mathrm{T}$ he latest skirmish in the battle between human and microbe played out on 29 November in a hotel conference room in Silver Spring, Maryland. There, an assembly of scientists and clinicians debated the merits of an experimental antibiotic. For some, the coveted prize was not just an endorsement of the drug itself, but a sign that the US Food and Drug Administration (FDA) is finally ready to rethink its clinical-trial requirements for antibiotics - requirements that the drug industry says are unrealistic.

The number of FDA approvals of new antibiotics has dropped even as multi-drugresistant strains of bacteria have proliferated. FDA advisers at last week's meeting did recommend approval of telavancin (Vibativ) - a derivative of vancomycin - for the treatment of hospital-acquired pneumonia when alternative drugs are not suitable. But that vote came nearly two years after the FDA had rejected the drug for a second time because clinical data did not measure up to the agency's guidelines.

"The agency has painted itself into a statistical corner," says Scott Hopkins, chief medical officer of Rib-X, a drug company in New Haven, Connecticut, focused on antibiotics. "While the infectious-disease community was crying out for new antibiotics, the FDA seemed to be going in the opposite direction."

Many trace the agency's tougher stance to the scandal surrounding telithromycin (Ketek), an antibiotic approved by the FDA in 2004 and later linked to liver failure (see 'Long and winding road'). In 2007, the US Congress launched an investigation into whether the FDA had ignored staff concerns about Ketek's safety. The following year, the agency convened its advisers to discuss antibiotics then under review. "Four drugs representing over a billion dollars of investment went into that week and only one came out alive," recalls Mark Leuchtenberger, president of Rib-X.

Telavancin was caught in the changing tides. When Theravance, the company in South San Francisco, California, that developed the drug, designed the large phase III clinical trials needed for approval, the FDA simply required a demonstration that the drug eliminated symptoms of infection as reliably as the approved antibiotic vancomycin. But, after Theravance submitted its second application on 30 June 2010, the FDA decided instead that applicants needed to show that patients were no more likely to die - of any cause - within 28 days of treatment with a new drug.

Theravance scrambled to gather the data, hunting down medical records for 1,419 out of the 1,503 patients scattered across dozens of countries that were enrolled in the telavancin trials. But the FDA determined that the study lacked statistical power and asked for new clinical studies. Theravance refused, and a stalemate followed.

Strict clinical guidelines for antibiotics have dogged the industry ever since, with pneumonia providing a good illustration. Patients who contract pneumonia in hospital are already ill, making it hard to know if the treatment under review played a part in their death. That means trials have to be larger to capture enough deaths to have any statistical meaning. This, combined with the relative rarity of infections that warrant the use of new antibiotics and the further FDA requirement that patients not receive other antibiotics before they get the experimental drug, has set the goal out of reach, argues David Shlaes, who runs Anti-Infectives Consulting in Stonington, Connecticut. Not a single new antibiotic for hospital-acquired pneumonia has been submitted for approval since the new guidelines were put in place. "The trial simply cannot be done," says Shlaes. "Whoever was writing these guidance documents doesn't live on the same planet that I do."

However, since the Ketek scandal, the political winds have reversed. This summer, Congress passed a set of measures to encourage antibiotic development. In May, Janet Woodcock, head of the FDA's Center for Drug Evaluation and Research, pledged to "reboot" the antibiotic-approval process. And in September, the FDA told Theravance that its advisers would take another look at telavancin, resulting in last week's vote.

Investors have also noticed these changes, says Leuchtenberger. Last week, Rib-X announced that it had raised US $\$ 18.7$ million to help the company start phase III trials of an antibiotic that could target skin infections. "Without some of these positive developments this year, you're looking at a number of companies that

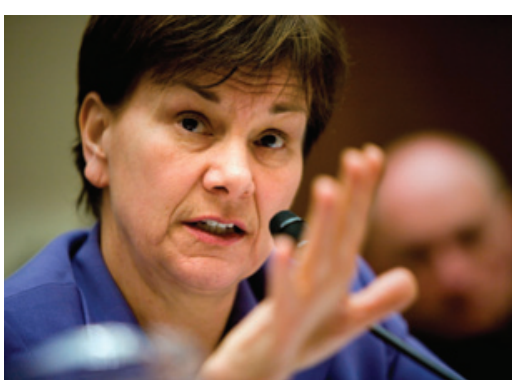

The FDA's Janet Woodcock.

\section{LONG AND WINDING ROAD}

US Food and Drug Administration (FDA) rules have hampered the approval of antibiotics.

\section{FEBRUARY 2007 The FDA} changes the label for the antibiotic Ketek to note risk of serious liver damage.

13 FEBRUARY 2007 Congress investigates the FDA's approval of Ketek.

\section{9-20 NOVEMBER 2008 FDA}

advisers reject three antibiotic

applications.

\section{JUNE 2010 Drug firm}

Theravance resubmits trial data to the FDA for approval of telavancin in hospital-acquired pneumonia.

\section{NOVEMBER 2010 The FDA}

proposes changes to guidance for approval of antibiotics to treat hospitalacquired pneumonia.

21 DECEMBER 2010 The FDA rejects telavancin for pneumonia and asks for additional clinical trials.

9 MAY 2012 Janet Woodcock, head of the FDA's Center for Drug Evaluation and Research, calls for a "reboot" of antibiotic evaluation.

\section{JUNE 2012 Congress approves} incentives for antibiotic development.

\section{NOVEMBER 2012 Telavancin} wins approval for the treatment of certain pneumonias.

might not be around any more," he says.

Shlaes, however, emerged from the telavancin meeting still doubtful, noting a continued focus on all-cause mortality. He says that, for now, he will continue to advise his clients to apply for approval in Europe first, where regulators have not been as demanding as the FDA. "I've been very optimistic about the whole thing," he says. "But the FDA has to do something to show that it is actually rebooting." - 